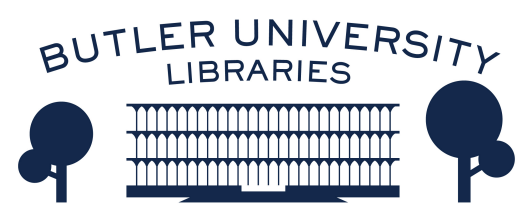

Journal of Hindu-Christian Studies

Volume 8

Article 7

January 1995

\title{
Viewpoints: Two Nationalist Poets on Jesus Christ
}

Prema Nandakumar

Follow this and additional works at: https://digitalcommons.butler.edu/jhcs

Part of the Religion Commons

\section{Recommended Citation}

Nandakumar, Prema (1995) "Viewpoints: Two Nationalist Poets on Jesus Christ," Journal of HinduChristian Studies: Vol. 8, Article 7.

Available at: https://doi.org/10.7825/2164-6279.1112

The Journal of Hindu-Christian Studies is a publication of the Society for Hindu-Christian Studies. The digital version is made available by Digital Commons @ Butler University. For questions about the Journal or the Society, please contact cbauman@butler.edu. For more information about Digital Commons @ Butler University, please contact digitalscholarship@butler.edu. 


\title{
Two Nationalist Poets on Jesus Christ
}

\author{
Prema Nandakumar
}

CHRISTIANITY IN INDIA is almost as old as Christianity itself. It is vain to think that Christianity can be seen as an isolable element in Indian culture. While the new religion settled down quietly in several parts of India, it naturally took on the Brahminic mode of life. The Syrian Christians in Kerala, for instance, are committed to a Brahminic custom like casting the horoscope and looking for a matching horoscope before finalizing a marriage. Father Beschi in Tamil Nadu donned Indian dress and wrote in Tamil. His poem Tembavani is justly famous. Each verse found in E. P. Krishna Pillai's epic, Rakshaniya Yatrikam, is an echo from Tamil hymnology like the Divya Prabhandham and Thevaram. Today we even have a Christu Bhagavatham which astutely relates the life of Jesus Christ to Vedic inspirations.

While being such a ubiquitous phenomenon in Indian tradition, Christianity also gave a good deal to the Indian culture. The 19th-century Renaissance gave a special fillip to this influence as an increasing number of Indians gained English education. Whether he studied law or philosophy or botany, the student drew close to Shakespeare and the Bible. The personality of Christ fired his imagination. As the Avatar theory was imbedded deep in the Indian's psyche, he thought of Christ as an incarnation of the Supreme come to the earth to save mankind. A deliverer in effect. Two of India's foremost nationalist poets received the Christ image on their poetry and they have left behind some memorable lines on the manifestation and ministry of the Son of Man.

Subramania Bharati (1878-1921) was an intense patriot who roused a sleeping nation with his powerful Tamil songs. A Vedantin, he has sung about many gods in the Hindu pantheon. He was an intense devotee of Shakti while the pellucid poems in his Kannan Pattu see the All-beautiful Krishna from various stances. Bharati had reverence for all religions and his "Jesus Christ" has three stanzas. It is a gem-like poem that refers to Mary Magdalene's vision of the Resurrection. The poetic version of Bharati penetrates into the inner core of the legend and comes out with admirable suggestions on the life and crucifixion of Jesus Christ. The entire poem is as follows:

"My Lord expired on the Cross and ascended in three days".

Beloved Mary Magdalene saw this happen.

Friends! Here's the esoteric sense. The gods will enter us

and guard us from all ills if we transcend pride.

Mary Magdalene is Love, Jesus the Soul.

The outer evil destroyed, the good life sprouts.

She praised the radiance in that golden face.

That was the love of Magdalene, ah, what joy!

If Sense is bound to the Cross of Truth, and crucified with nail austerity,

Jesus of the strengthened soul will rise as the boundless sky.

Magdalene is Eternal Feminine, Jesus Christ is deathless dharma,

Draw we close to the symbol: look, an inner meaning glows. ${ }^{1}$

Bharati is not giving here a philosophical disquisition on the phenomenon of Christ. The image of Christ on the Cross kindles the poet in him. Why is there so much suffering? Must godliness, holiness and 
goodness be ever at the mercy of materialist, power-proud Pilates? As the heart grows arid with such questionings, the ascension opens the nectarean stream, Hope. The next step is identifying the poetic experience in terms of Bharati's received tradition which is Brahminic and Vedantic.

Coming in the line of a race that has considered man as a child of immortality (srinvantu viswe amruthasya putrah), Bharati avoids seeing the crucifixion as a sacrifice to redeem a sinful humanity. The ministry of Christ is to transform man and that is done by guarding us from the afflictions of the mind and the spirit. Indeed, the Lord's spirit becomes embedded in our consciousness. This constant god-consciuosness transforms human clay into a divine vessel.

How shall we coax the Lord to enter our consciousness, make us carriers of the imperishable dharma? By love, of course! Subramania Bharati sees Mary Magdalene as love incarnate. Love is the hoop of the gods to combine the human being, Jivatman, and the Supreme, Paramatman. Where love is, all smallnesses fall away. Where love is expressed with electric ease, the Divine appears automatically for God is Love. The Supreme never fails to respond to the sincere aspiration of the human being.

Again, Bharati is the child of a culture that has set great store by yoga. Selfdiscipline to attain perfection has been a way of life for the Indian. Subramania Bharati's penetrative eye sees a yogic stance in the image of the Cross. If our senses are brought under control by a strict selfdiscipline that is based on Truth, if simplicity and austerity are followed in this adventure of self-perfection, we will be transformed as carriers of the Pratyagatman, the Indwelling Universal, Jesus Christ. We will then be boundless and merge with the infinite. It is the Vedantic stance outlined by Bharati in his poem, "Beat the Drum":

The crow and the sparrow are of us, the sea and the mountain are of us,

'tis ourselves everywhere we see, and the heart dances with delight.
Beat the drum $!^{2}$

The Avatar who suffers on earth for the sake of man is always seen as an image of Dharma, for the incarnation takes place to destroy the unrighteous and guard the good in humanity. Rama, for instance, is called vigrahavan dharmah: image of Dharma. Where is death for Dharma, the Eternal Law? The Resurrection but proves the eternal nature of Dharma. For Bharati Mary Magdalene symbolizes the devotion-laden heart of man (which is the eternal feminine in all of us) that lovingly worships the Eternal Bridegroom, to help the union take place for transforming life on earth into a life divine.

Another great patiiot poet of Indian Renaissance, Sri Aurobindo (1872-1950) was also drawn to the image of Christ on the Cross. Sri Aurobindo had delved deep in the classics of the West and was particularly drawn to The Divine Comedy. He notes with pleasure Dante's ability in using simple words for achieving profound effects:

... poetry can be great or perfect even if it uses simple or ordinary expression e.g. Dante simply says "In His Will is our peace" (E'n la sua volantade é nostra pace) and in writing that in Italian produces one of the greatest lines in all poetic literature. ${ }^{3}$

The life and sayings of Christ were readily used by Sri Aurobindo as illustrations in his writings. While explaining the significance of the Avatar for man's spiritual progress, he said:

It has always been supposed by spiritual people that divine perfection, similitude to the Divine, sadrisya, sadharmya is part of the Mukti. Christ said "Be ye perfect as your Father in Heaven is perfect" - the very Divine himself, mind you, not a mere Avatar of luminous projection from him. His followers strive to be Christlike. Thomas a Kempis, meditating and striving, wrote a book on the Imitation of Christ. Francis of Assisi and many others arrived at Christlikeness. ${ }^{4}$ 
A key passage in Sri Aurobindo's epic poem in English, Savitri, takes up the Christ image as an illustration for the Avatar theory. When the Divine incarnates as an Example, necessarily the human attributes include suffering on earth. It is a tremendous sacrifice on the part of the Divine to incarnate so, says Aurobindo in the short poem "A God's Labour":

He who would bring the heavens here Must descend himself into clay

And the burden of earthly nature bear And tread the dolorous way.

Coercing my godhead I have come down Here on the sordid earth,

Ignorant, labouring, human grown Twixt the gates of death and birth. ${ }^{5}$

Though the Avatar comes down to help man, he is rejected fiercely by men themselves who cry out in their ignorance:

This earth is ours, a field of Night for our petty flickering fires.

How shall it brook the sacred Light Or suffer a god's desires?

Come, let us slay him and end his course! Then shall our hearts have release

From the burden and call of his glory and force

And the curb of his wide white peace. ${ }^{6}$

Sri Aurobindo's Savitri posits Savitri as an incarnation of the Supreme who struggles with Death (Ignorance, Nescience) and gains back the soul of the world called Satyavan. Savitri, a daughter of King Aswapathy, chooses Satyavan as her husband. Rishi Narad tells her and her parents that Satyavan has but one year to live. Immediately Aswapathy's Queen requests Savitri to change her decision and choose another. Savitri rejects the proposal:

Once my heart chose and chooses not again...

Death's grip can break our bodies, not our souls;

If death take him, I too know how to die.

Let Fate do with me what she will or can; I am stronger than death and greater than my fate;
My love shall outlast the world, doom falls from me

Helpless against my immortality.

Fate's law may change, but not my spirit's will. $^{7}$

The Queen in sheer frustration asks Rishi Narad why it becomes the lot of human beings to experience pain, separation, death. It is here that Rishi Narad unveils the Avatar theory and insinuates that Savitri is one such Avatar. For an illustration he brings in Christ's Passion. In the transformative logic of a poet's epic pronouncement, it appears quite natural for an ancient Indian seer like Rishi Narad to use an illustration that is not yet 2000 years old! Thus Rishi Narad to the Queen:

It is finished, the dread mysterious sacrifice,

Offered by God's martyred body for the world;

Gethsemane and Calvary are his lot,

$\mathrm{He}$ carries the cross on which man's soul is nailed;

His escort is the curses of the crowd;

Insult and jeer are his right's acknowledgement;

Two thieves slain with him mock his mighty death.

He has trod with bleeding brow the Saviour's way.

He who has found his identity with God

Pays with the body's death his soul's vast light.

His knowledge immortal triumphs by his death.

Hewn, quartered on the scaffold as he falls

His crucified voice proclaims, "I, I am God;"

"Yes, all is God", peals back Heaven's deathless call.

The seed of Godhead sleeps in mortal hearts,

The flower of Godhead sleeps in mortal hearts,

The flower of Godhead grows on the world-tree:

All shall discover God in self and things.

But when God's messenger comes to help the world

And lead the soul of earth to higher things, 
He too must carry the yoke he came to unloose;

He too must bear the pang that he would heal:

Exempt and unafflicted by earth's fate,

How shall he cure the ills he never felt? ${ }^{8}$

The poet's intuitive vision thus integrates Christ's Passion and the Avatar theory into a profound image full of lasting significances. The West may be West and the East may be East, but the twain can after all meet thus in the spaces of man's soul with perfect concordance to take a definitive step towards human unity.
Notes

1. Translated by Prema Nandakumar.

2. Translated by Prema Nandakumar.

3. Nirodbaran, Correspondence with Sri Aurobindo. Vol. II (Pondicherry: Sri Aurobindo Ashram, 1984) p.1046.

4. Ibid. p.173.

5. Collected Poems (1989) p.99.

6. Ibid. p.101.

7. Savitri (1954) p.490.

8. Ibid. pp.504-5. 